\title{
A német Panzer III-as közepes harckocsi
}

$\mathrm{T}$ alán kijelenthető, hogy azon nem haditechnikai szakemberek számára, akik a militária témakörön belül a harckocsik iránt érdeklődnek, az ezzel a fegyvernemmel kapcsolatban felmerülő nevek, mint a Tigris, Párduc, Sztálin, vagy Sherman jelentik „a” tankot, „a” páncélost.

Pedig ezek a harceszközök nem a semmiből, előzmények nélkül születtek meg.

Valamennyi létrejöttét hosszú fejlesztés, korábbi példányok és változatok előzték meg, mindig hosszú út vezetett a németek által „szuggesztív név”-vel, illetett (de minden nemzet esetében érvényes) híres típusok megszületéséhez.

A német harckocsi-fejlesztésben az első, már kiforrott, valóban használható páncélosok, amelyeket nem kis részben Guderian elképzelése szerint terveztek meg, a Pz III és Pz IV típusok voltak. Rendszeresítésüktől kezdve - mint a harckocsik között kevés - a háború teljes ideje alatt szolgálatban maradtak. Ezek segítették a német hadsereget az első évek sikereihez, és a háború második felében igyekeztek feltartóztatni az összeomlást.

Természetesen az évek során számtalan módosítással, de alapkoncepciójuk változatlanul hagyása mellett harcolták végig a háborút.

Tulajdonképpen a Pz I és Pz II „Übungsgerät” (gyakorló eszköz) harckocsik megtervezésével és előállításával szerezte meg a német ipar azt a tudást, amire a következő két típus gyártásához szüksége volt.

Guderian, a későbbi vezérezredes, kétféle harckocsi létrehozását igényelte a német ipartól.

1. ábra. A Pz III-as harckocsi futómúvének egymást követő változatai. Az E típustól készült páncélteknők oldalsó kibúvónyílásai az $\mathrm{L}$ változatnál már elmaradtak

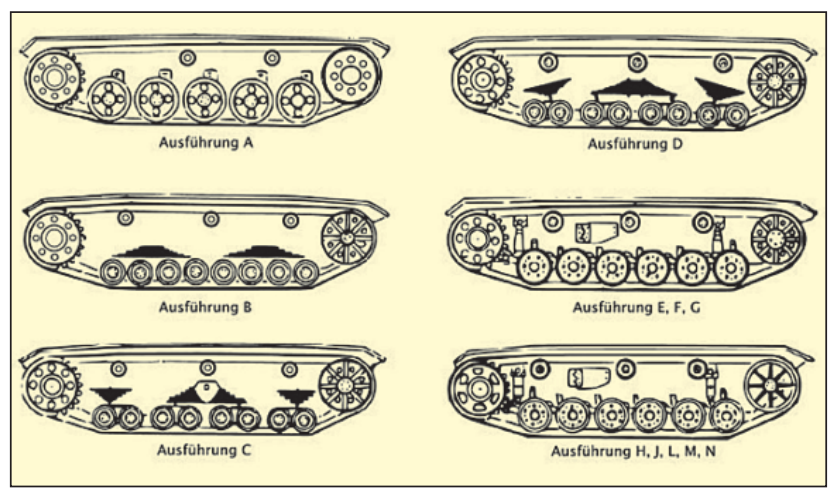

ÖSSZEFOGLALÁS: A németek az 1938-ban megjelent új Pz III típusnál alakították ki a bevált 5 fös személyzet alkalmazását. A 14,5 - 5 mm-es páncélzattal kialakított harckocsi tömege 15,4 t volt. Meghajásáról 12 hengeres, 250 LE-s motor gondoskodott. A páncélos a német-lengyel háborúban (1939) esett át a tűzkeresztségen.

KULCSSZAVAK: II. világháború, német haderő, páncélos hadviselés, Pz III harckocsi

ORCID: 0000-0002-1526-029X

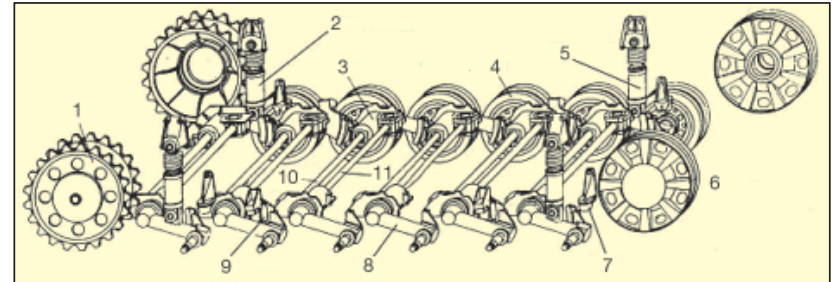

2. ábra. A torziós rugózású futómű áttekintő rajza

1 - meghajtókerék; 2 - első lengéscsillapító; 3 - lengőkar csapágyazása; 4 - futógörgő; 5 - hátsó lengéscsillapító; 6 - vezető-feszítőkerék; 7 - gumibetétes ütköző; 8 - lengőkar; 9 - lengőkar vezető ütközővel; 10 - torziós rugó a jobb oldali görgőhöz; 11 - torziós rugó a bal oldali görgőhöz

Egyet, amely páncéltörő fegyverrel van felszerelve és egy másik, „támogató” páncélost, egy nagyobb kaliberű ágyúval.

Mindkét típus esetében szükségesnek látta két géppuska beszerelését is. Egyet a toronyba, a lövegcsővel párhuzamosítva, a másikat mozgathatóan a homlokpáncélba építve.

Ebből az elképzelésből született meg a III-as és IV-es típusú harckocsi, amelyek közül a tervezett páncélos zászlóaljak három könnyú századát a Pz III-asoknak, a negyedik, támogató század harckocsi állományát a Pz IV típusnak kellett alkotnia.

Ezeknél a típusoknál alakították ki a bevált és végig megtartott 5 fős személyzetet, amelyet a háború folyamán a legtöbb ország páncélosainál is bevezettek.

A'30-as évek elején, amikor más országokharckocsijaiban a parancsnok hátulról, a vezető vállainak rugdosásával jelezte a kívánt irányt, a német harckocsikban már kétféle rádió-berendezés is a személyzet rendelkezésére állt. $A z$ egyik a belső, a páncéloson belüli kommunikációhoz, a másik pedig a parancsnoknak a többi harckocsival, vagy a parancsnoksággal való kapcsolattartásához.

Ma már ezek maguktól értetődő alapelvárások, de akkoriban mindez óriási előnyt jelentett a német harckocsizók számára.

Mindezek lényeges szerepet játszottak a „villámháborús" sikerekben, hiszen a háború első szakaszában a német páncélosok a Pz III és Pz IV típusokkal olykor gyengébb páncélzat, és kisebb kaliberű lövegek mellett is meghaladták az ellenfél harckocsicsapatainak harcértékét.

A Pz III harckocsi megszületésekor a Hadsereg fegyverzetügyi hivatala és a Kraftfahrtkampftruppen (gépesített csapatok) képviselői között kemény viták folytak annak

ABSTRACT: The German applied the crew of five for the new type Pz III that appeared in 1938 and proved to be good then. The mass of the tank designed with $14,5-5 \mathrm{~mm}$ armour was 15,4 ton. It was driven by a 12-cylinder motor of 250 HP. The battle baptism for the tank occurred in the German-Polish war in 1939.

KEY WORDS: World War II, German armed forces, tank warfare, Tank Pz III 


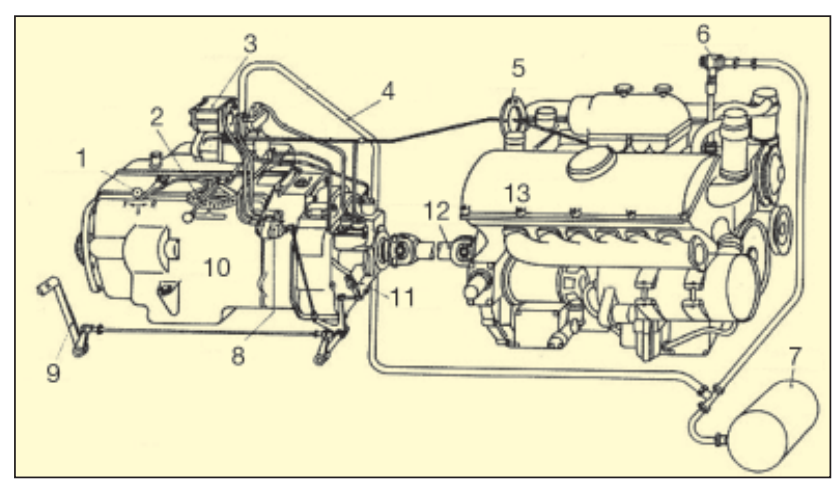

\section{A harckocsimotor és sebességváltó rajza}

1 - menetirányválasztó-kar; 2 - előválasztó kar; 3 - kapcsolószekrény; 4 - vákuumvezeték; 5 - gázhuzal; 6 - visszacsapószelep; 7 - vákuum tartály; 8 - kioldó szelep; 9 - kuplungpedál; 10 - sebességváltó; 11 - fő-kuplung; 12 - kardántengely; 13 - Maybach HL 120 TRM motor

fegyverzete körül. A fegyverzetügyi hivatal - részben hivatkozva az egyszerűbb alkatrész- és lőszerellátásra - kielégítőnek tartotta az amúgy is rendszerben lévő $3,7 \mathrm{~cm}$-es páncéltörő ágyú beépítését. A Gépesített csapatok által javasolt $5 \mathrm{~cm}$-es löveg beépítését nem látták indokoltnak. Arra a kompromisszumra azonban készek voltak, hogy már az első toronyváltozat is később képes legyen egy $5 \mathrm{~cm}$-es ágyú esetleges befogadására.

A tervek szerint a megtervezendő harckocsi harci tömege nem lehetett több mint 24 tonna, a maximális sebessége pedig el kellett, hogy érje a $40 \mathrm{~km} / \mathrm{h}-\mathrm{t}$.

Részben ezekkel az elvárásokkal a Heereswaffenamt (hadsereg fegyverzetügyi hivatala) 1935-ben 4 céget (a nürnbergi MAN-t, a Berlin-marienfeld-i Daimler-Benz AG-t, a berlini Rheinmetal-Borsigot és az esseni Krupp AG-t) bízott meg a mintapéldány megtervezésével és megépítésével.

A kialakított mintapéldányok nem kis részben a megbízott cégek saját, fő tevékenységi körét tükrözték. PI. a Daimler-Benz-nél inkább a gépkocsiknál, a Krupp-nál pedig a mozdonygyártásban általános megoldásokat alkalmaztak (pl. torziós vagy laprugós kerékfelfüggesztés).

Az első páncélosok már 1936-ban készen álltak a hadsereg próbáira.

Ezek megtörténte és kiértékelése után a további fejlesztéssel és a gyártással a kiválasztott Daimler-Benz céget

\section{4. ábra. A lövegirányzó kezelőszervei a toronyban}

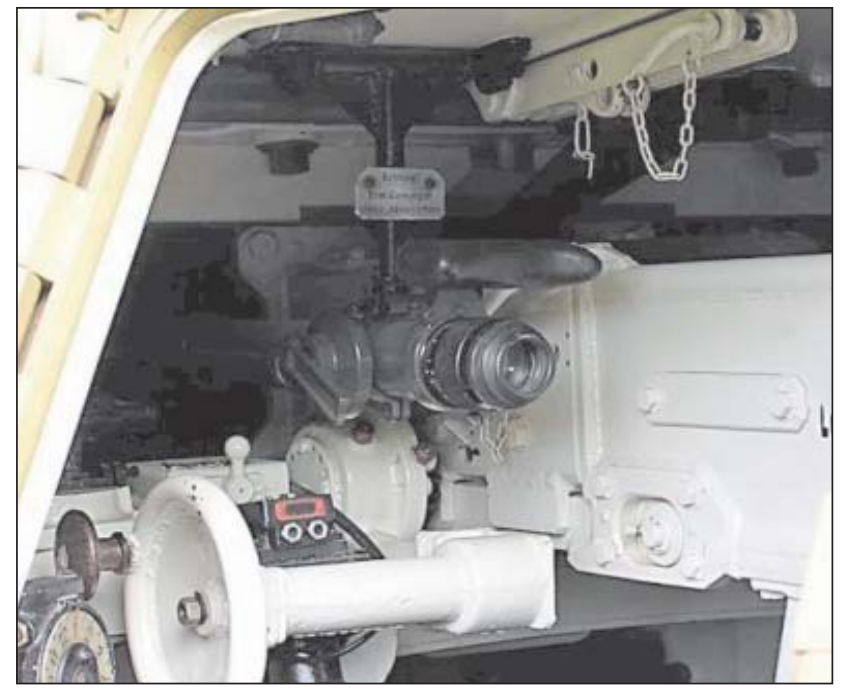

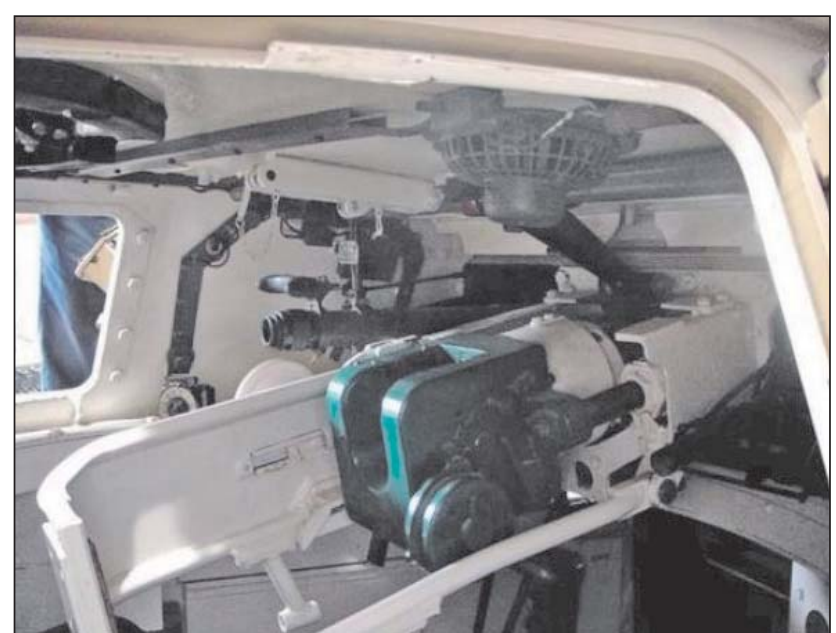

5. ábra. A toronyba épített $5 \mathrm{~cm}$-es löveg jobb oldali nézete

bízták meg, amely részvénytársaság az akkor Typ 1/ZW-

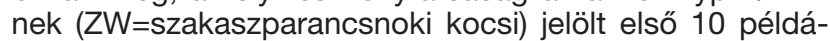
nyát 1937-ben már átadta csapatpróbákra.

Ezek közül 8 harckocsi 3,7 cm-es löveggel volt felszerelve. Bár a páncélos általános felépítésében már emlékeztet a későbbi Pz III-as harckocsira, öt nagy futókereke még tekercsrugókra volt felfüggesztve. A 14,5 - 5 mm-es páncélzattal kialakított harckocsi tömege 15,4 t volt.

Meghajtásáról a Maybach cég fejlesztette 12 hengeres, 250 LE-s 108TR motor gondoskodott, amely a harckocsinak $32 \mathrm{~km} / \mathrm{h}$ maximális sebességet biztosított. Sebességváltója egy ZF SFG 75 mechanikus típus volt, 5 előre- és 1 hátramenettel. Az immáron hivatalos megjelölés $P z$ III (3,7 cm) Ausführung (változat) A lett.

Már 1938-ban megjelent az új Pz III Ausführung B (Typ „2/ZW") változat, amely elődjétől elsősorban módosított futóművével különbözött. Az oldalanként összesen 8 futógörgőt két csoportba fogta össze egy-egy kettős lengötest, amelyek laprugókkal csatlakoztak a páncélteknőhöz.

Az 1937-38-ban gyártott Ausführung $C$ ismét más futókerék-felfüggesztést kapott. A görgők itt párosával voltak külön laprugókra szerelve.

Az Ausführung $D$ futóműve ismét kisebb változáson esett át, és más, egy ZF SSG 76-os sebességváltót kapott. A $30 \mathrm{~mm}$-re emelt alappáncélzat a harckocsi tömegét 19,8 t-ra növelte.

Ennek a változatnak volt egy parancsnoki változata is, amelybe erősebb rádió-berendezéseket, és a löveg helyett csak egy utánzatot építettek. Ez a parancsnoki kialakítás a későbbi sorozatok egy részénél is megmaradt.

Az 1939-től 1940-ig gyártott Pz III Ausführung E a prototípus-fejlesztés utolsó változata volt.

Lényeges különbség volt az elődeinél nagyobb lökettérfogatú, „HL 120 TR” jelzésű erősebb, 320 LE-s motor. A típusba beépített ugyancsak új, a maga korában rendkívül korszerü, de bonyolult Maybach-Variotex előválasztós sebességváltó 10 előremeneti és egy hátrameneti fokozattal rendelkezett. A vezetőnek csak ki kellett választani a megfelelő sebességfokozatot, amely után a kapcsolás a kuplung benyomásakor vákuum segítségével történt. A kormányzás mechanikus szervo rásegítéssel működött.

Ennek a változatnak a jellemzően hat görgős, a páncélteknőben keresztbe épített torziós rudakra kapcsolt futóműve a további teljes gyártás alatt már változatlan maradt.

Idős, a háború alatt több típuson is szolgált harckocsizók véleménye szerint ennek a harckocsinak volt a legfino- 


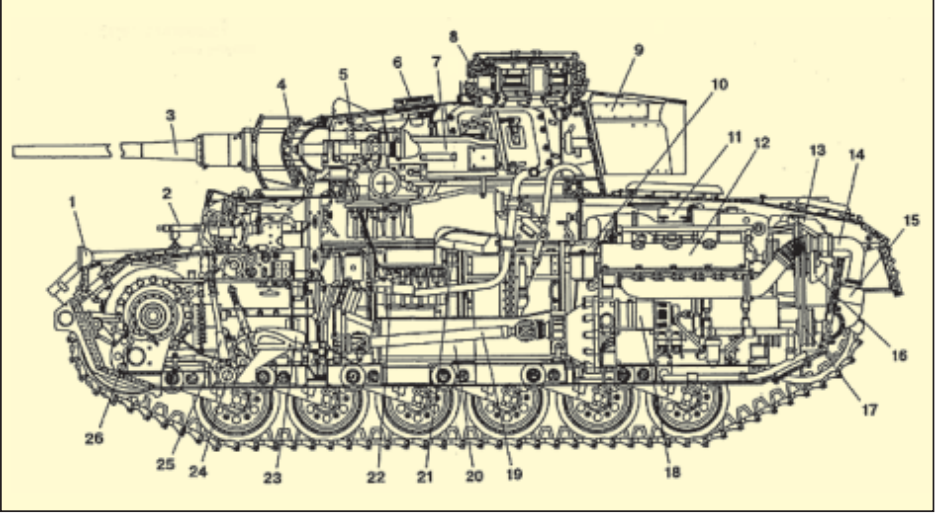

6. ábra. A Pz III-as harckocsi metszeti rajza

mabb a rugózása. (Ebben a vonatkozásban a legkevésbé kedvelt a IV-es típus volt).

A Pz III-as homlokpáncélját az E-től a $\mathrm{H}$ változatig terjedő módosítások során felhegesztett páncéllapokkal 30 mm-re növelték.

Ezt, a Pz. III-as változatot szánták a páncélos ezredek feltöltésére, a Wehrmacht a harckocsit rendszeresítésre és alkalmazásra is megfelelőnek ítélte. Azonban az E típusból - a német hadiipar akkori alacsony teljesítőképessége miatt - csak kevés példány épült meg.

Nagyobb sorozat szállításához más gyártóműveket is be kellett kapcsolni, így az Altmärkische Kettenfabrik GmbH-t (Alkett), a Fahrzeug- und Motorenbau GmbH-t (FAMO), az MAN AG-t és további 5 céget vontak be a munkákba.

A páncélosok gyártását legnagyobb részben azonban az Alkett cég végezte.

Időközben - 1938 januárjában - a Heereswaffenamt elrendelte a páncélos továbbfejlesztését, elsődlegesen az addig beépített löveg helyett az $5 \mathrm{~cm}$-es L/42-es ágyúra történő átfegyverzést, amelynek torkolati sebessége az alkalmazott lőszertől függően 450 - $650 \mathrm{~m} / \mathrm{sec}$ volt.

A páncélos a német-lengyel háborúban (1939) esett át a tűzkeresztségen. Akkor még egyetlen, a harcokban részt vett harckocsi sem rendelkezett az $5 \mathrm{~cm}$-es löveggel, az így harcérték-javított páncélosok először 1940 májusa után, a Franciaországgal vívott harcok során kerültek a harckocsicsapatokhoz. Még ugyanezen év februárjában is közel 50 kisebb, $3,7 \mathrm{~cm}$-es ágyús változatot kapott a német hadsereg.

Az immáron $5 \mathrm{~cm}$-es löveggel szerelt, $P z$ III Ausf. $F$ volt az első nagy szériában gyártott változat. Az ezekbe szerelt Maybach HL 120TRM motorok már 250 - 300 LE teljesítményt adtak le. A módosítások miatt megnövekedett tömegű páncélos egyik jellemzője - ettől kezdve - a torony hátsó páncéljára szerelt szerelékes láda.

A korábbinál hosszabb cső miatt a vezető elé két kontroll lámpát építettek be, amelyek kék színükkel akkor jeleztek, ha a lövegcső pillanatnyi helyzete a harckocsi szélességén jobb vagy bal irányban túlnyúlt.

Az 5 cm-es löveggel szerelt változatból összesen 1924 példány készült.

A Pz III Ausf. G külsőre a más típusú parancsnoki kupolájával tért el elődeitől. Az afrikai harcokban is nagyobb számban bevetett harckocsik (,Tp” = trópusi) hűtő és levegőszűrő berendezéseit is illesztették a meleg, poros feltételekhez, pl. a motor a müködéséhez szükséges levegőt a kűzdőtéren át szívta be. Mindezek ellenére a motorok számára (is) barátságtalan környezetben az átlagos futásteljesítmény ritkán haladta meg a 3000 km-t.

Az afrikai harcokban az angol páncéltörő lövegek megjelenése a páncélzat erősítését tette indokolttá. A homlokle-

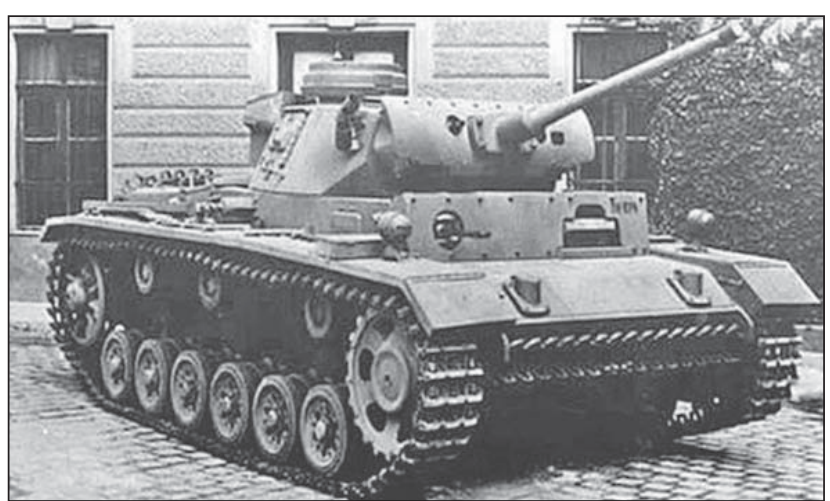

7. ábra. A Magyar Honvédségnek átadott 1H 874 rendszámú, $M$ változatú páncélos a Haditechnikai Intézet udvarán

mezre 30 mm-es kiegészítő páncéllapot szereltek. A farpáncélt is hasonló módon megerősítették, hogy a harcjármű ne váljon fejnehézzé, tudomásul véve az ezzel megnövekedett, már 21,6 t harci tömeget. Mindez megkövetelte erősebb torziós rudak beépítését is a futóműbe.

Az 1940-1941-ig gyártott, erősített védelmű harckocsik a $P z$ III Ausf. $H$ megjelölést kapták.

A nagyobb tömeg nyomán megemelkedett talajnyomás szükségessé tette a lánctalp szélességének 360-ról 400 mm-re történő növelését is. Ennél a változatnál cserélték le az addig beépített előválasztós sebességváltót egy hagyományos, mechanikus változatúra, 6 előre és egy hátramenettel.

Mindezek a harcértékjavító intézkedések is kevésnek bizonyultak azonban a szovjet T-34-es és KV harckocsik ellen. Így 1941-től bevezették a 39 mintájú, 5 cm L/60-as harckocsiágyút, 3000 mm-es csőhosszúsággal. Ennek a lövegnek a torkolati sebessége az űrméret alatti Panzergranate 40-es lőszerrel $1180 \mathrm{~m} / \mathrm{sec}$ volt.

Ezeket a lövegeket már sorozatban építették be a $P z$ III Ausf. J típusokba, és valamennyi Németországba nagyjavításra visszaszállított páncélosba is.

A Pz III teljes gyártási ideje alatt több kivitelből is készült parancsnoki és megfigyelő harckocsi. Ezeknél, a több rádiókészülék beépítése miatt, a csapatok minden tiltakozása ellenére elhagyták a löveget, amelyet azután fából, vagy lemezből készült csőutánzattal helyettesítettek. A hiányzó fő fegyver sokszor a legnehezebb helyzetekben tette lehetetlenné, hogy a parancsnoki páncélos megvédje önmagát. 1941 januárjában a Daimler-Benz AG-ot megbízták az L/42-es, illetve L/60-as löveggel is felszerelt változat kialakítására, ahol a töltőkezelő a 2 . rádiós feladatát is megkapta. Ezek, a közel 200 példányban készült harckocsik a Pz III

8. ábra. A HTI által vizsgált Pz III-as páncélos hátulnézeti képe. A megemelt, visszacsapó szelepes kipufogódob a nagyobb gázlóképességre utal

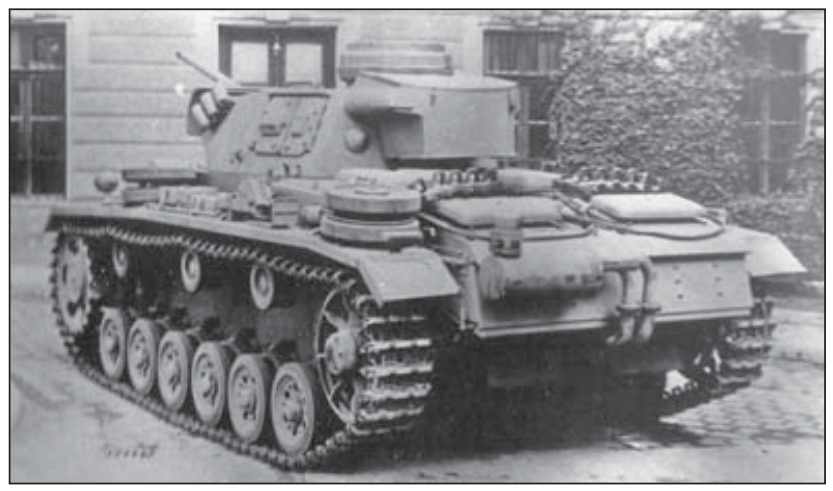




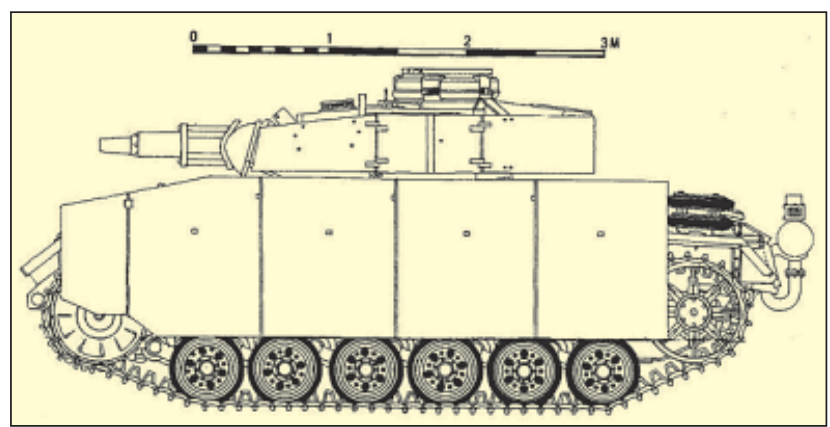

9. ábra. Az N változat oldalnézeti rajza páncélteknő- és torony-kötényezéssel

Ausf. K Panzerbefeh/swagen (parancsnoki harckocsi) megnevezést kapták. Az utolsó darabok 1943 augusztusában kerültek a csapatokhoz.

Még 1941 végén megkezdték az Ausf.L kiszálítását, amelynél ismét megerősítették a test és a torony homlokpáncélját. Emiatt a páncél vastagsága már $60 \mathrm{~mm}-\mathrm{re}$, harci tömege 22,3 t-ra emelkedett. Néhány példányt kónikus csövű löveggel szereltek fel, amely komoly teljesítménye ellenére sem maradt hosszan alkalmazásban, mert a lövedékek gyártásához szükséges molibdénacél Németországban már nem állt rendelkezésre.

A harckocsi következő változata a $P z$ III Ausf. $M$ volt. Jellemzője, hogy 1942 végétől ezt a típust átfegyverezték a 7,5 cm-es L/24-es harckocsiágyúra, amely a korai Pz IV típusok lövege volt. Az így 23 t tömegű harckocsik egy részének gázlómélysége néhány módosítás nyomán nagyobb (1300 mm) lett, valamint - takarékossági és gyártástechnikai okokból - a páncéltesten és a tornyon több kitekintő nyílást elhagytak.

A Pz III-as utolsó sorozatban készült változata az Ausf $N$ volt, amelyet 1942-ben és 1943-ban gyártottak. Ezeket a páncélosokat már gyárilag a 7,5 cm-es L/24-es löveggel szerelték fel. Ebből a harckocsiból összesen 660 példányt készítettek.

A Pz III típus sok évig futó gyártása során több, kisebb darabszámú változat is készült. Ezek közé tartozott az Ausf. FI ( = Flamm=láng) lángszórós kivitel, amely 1000 I lángolajjal feltöltve kb. 70-80 lángcsapást volt képes vetni, mintegy 70 méteres távolságra.

Ide sorolható a Panzerbeobachtunswagen III-as (páncélos megfigyelő kocsi), amelyet a fedélzeti, belső kommunikációs rendszerén kívül további négy különböző rádió-berendezéssel is felszereltek. (llyenből maradt többek között Budapesten, a városért folytatott harcok után; egy-egy példány a Naphegyen és a Tabánban.)

10. ábra. A német 3. páncélos hadosztály Pz III Ausf. M harckocsija Magyarországon. A toronyra és a rakodóládára terített sátorlap a beszivárgó eső ellen védett

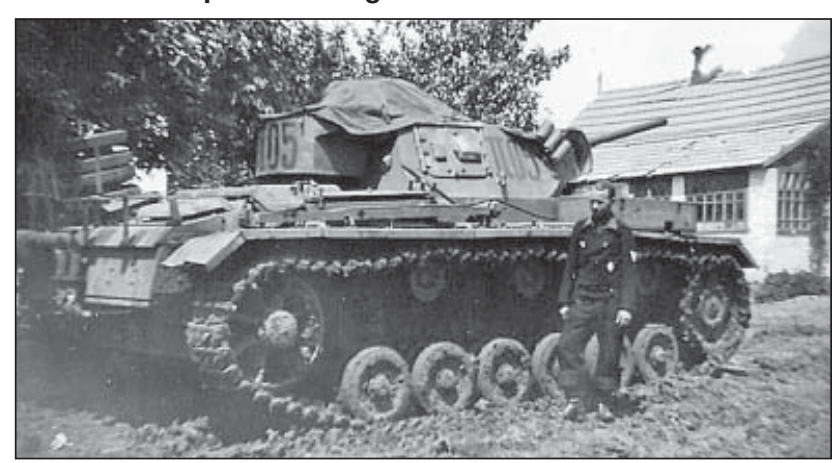

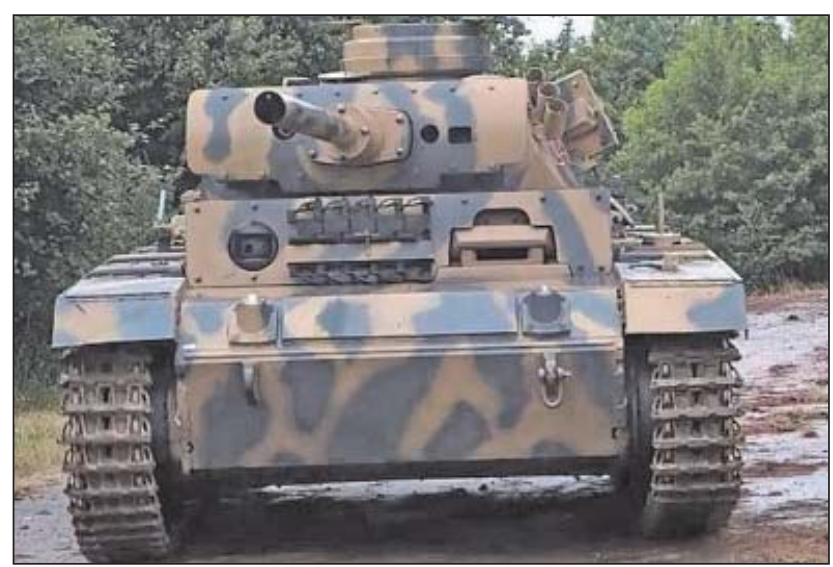

11. ábra. A Munster-Lager-i páncélos múzeum lángszórós harckocsija

Készült műszaki mentő változat is, általában a sérült páncélosokból, amely először csak vontatásra, később már frontközelben végzett kisebb munkákra, de lőszerszállításra is alkalmas volt.

Meg kell említeni, hogy 1943-tól a páncélosokat mindkét oldalon $5 \mathrm{~mm}$ vastag, páncéltörő puskák és kumulatív lövedékek elleni acéllemez kötényzettel látták el. Ugyancsak ettől az évtől kezdve a Pz III-as harckocsik egy részét mágneses aknák elleni védekezésként zimmerit bevonattal látták el, amiből egy ilyen típushoz kb. 100 kg anyagra volt szükség.

A keleti front különösen kedvezőtlen út- és terepviszonyai miatt 1944 végén bevezették a szélesített (addigi 38, majd 40 helyett $56 \mathrm{~cm}$ széles) Ostkette-t (keleti lánctalpat). Ez a lánctalp, bár kisebb fajlagos talajnyomást biztosított a harckocsinak, azonban aszimmetrikus kialakítása miatt erősen megterhelte a futómű elemeit. A páncélos szélessége ezzel 3266 mm-re növekedett.

A Panzerkraftwagen III-as gyártását 1943 augusztusában leállították, az így felszabadult szinte teljes gyártási kapacitást a Pz III-as fő elemeire alapozott StuG III-as (rohamlöveg) előállítására fordították, amely azután a háború utolsó éveinek elhárító harcai során meghatározó páncélos fegyverré vált.

Összefoglalva megállapítható, hogy az 1935-től 1945-ig összesen 15350 példányban gyártott Pz III-as, StuG III-as, és ezek valamennyi változata megbízható harcjármü volt, amelyek a mindenkori lehetőség határain belül be is váltak, ellentétben a későbbi, harcértékben lényegesen többet nyújtó német harckocsikkal, amelyeknek komplikált, esetenként ki nem forrott technikai megoldásai több gondot okoztak a harckocsikat javító/karbantartó múszaki alakulatoknak.

12. ábra. A harckocsi lángvető csöve, és elemei

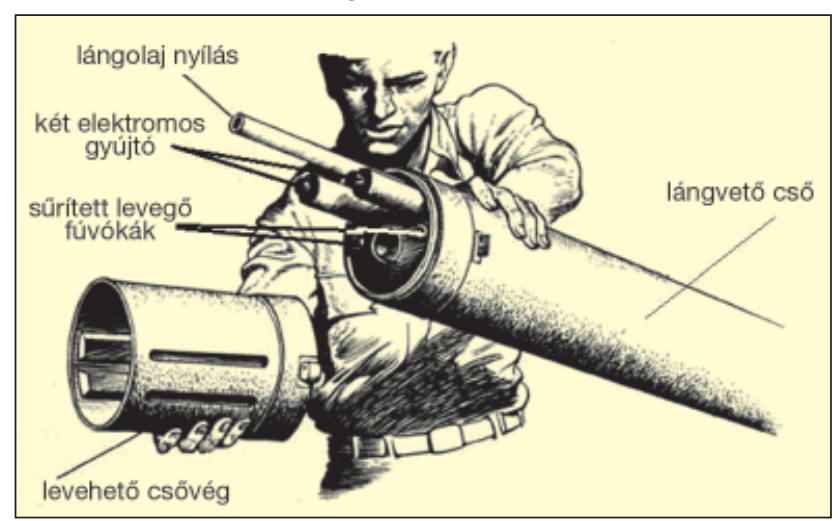


1. táblázat. A Pz III típusú páncélosok évente gyártott mennyisége, a beépített lövegek szerinti bontásban

\begin{tabular}{|c|c|c|c|c|c|c|c|c|}
\hline & 1937 & 1938 & 1939 & 1940 & 1941 & 1942 & 1943 & Összesen \\
\hline 3,7 cm L/45 & 38 & 33 & 206 & 391 & & & & 668 \\
\hline $5 \mathrm{~cm} \mathrm{L/42}$ & & & & 476 & 1673 & 251 & & 2400 \\
\hline $5 \mathrm{~cm} \mathrm{L/60}$ & & & & & 40 & 1907 & 22 & 1969 \\
\hline $7,5 \mathrm{~cm} \mathrm{L/24}$ & & & & & & 450 & 213 & 663 \\
\hline Összesen & 38 & 33 & 206 & 867 & 1713 & 2608 & 235 & 5700 \\
\hline
\end{tabular}

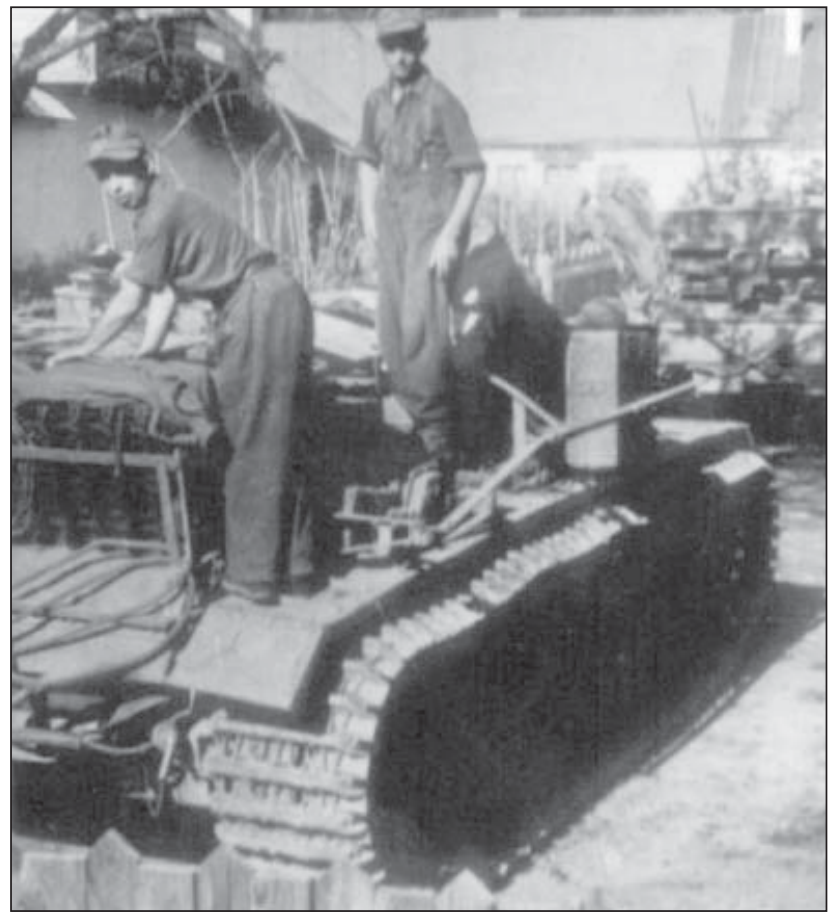

13. ábra. A típus „keleti lánctalp”-pal (Ostkette) szerelt müszaki mentő változata. Ennek a lánctalpnak tagjai egyenként 11,9 kg tömegüek és $56 \mathrm{~cm}$ szélesek voltak

A Pz III-as harckocsi a Magyar Királyi Honvédség páncélos állományában is jelen volt.

A keleti front 1942-es súlyos csatái során a magyar 30. ezred páncélos állománya olyan veszteségeket szenvedett, hogy a németek számára is fontos harckészség fenntartása céljából a Wehrmacht több, 7,5 cm-es L/43-as löveggel felszerelt Pz IV F és G típusú harckocsi mellett $10 \mathrm{db}$

14. ábra. Egy lőszerszállító változat. Érdekes a jobb oldali kötényen oldalt kivágott, oldalsó kitekintést biztosító két nyílás. A felbillentett tető robbanótestek bedobása ellen védett

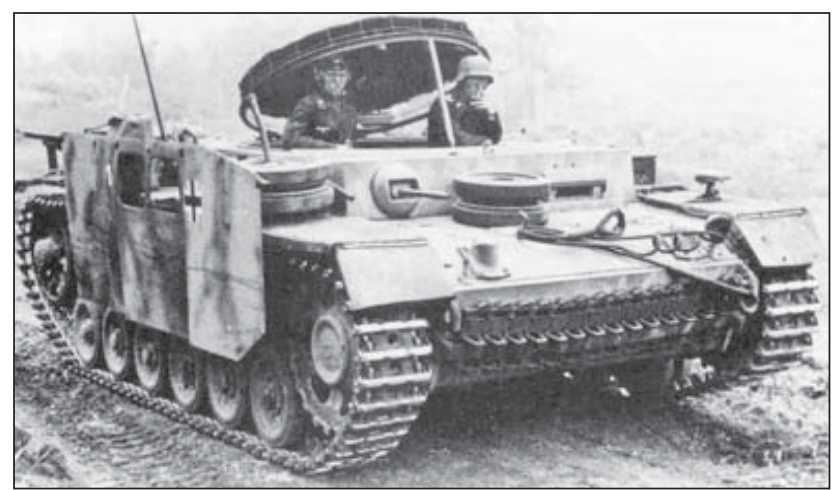

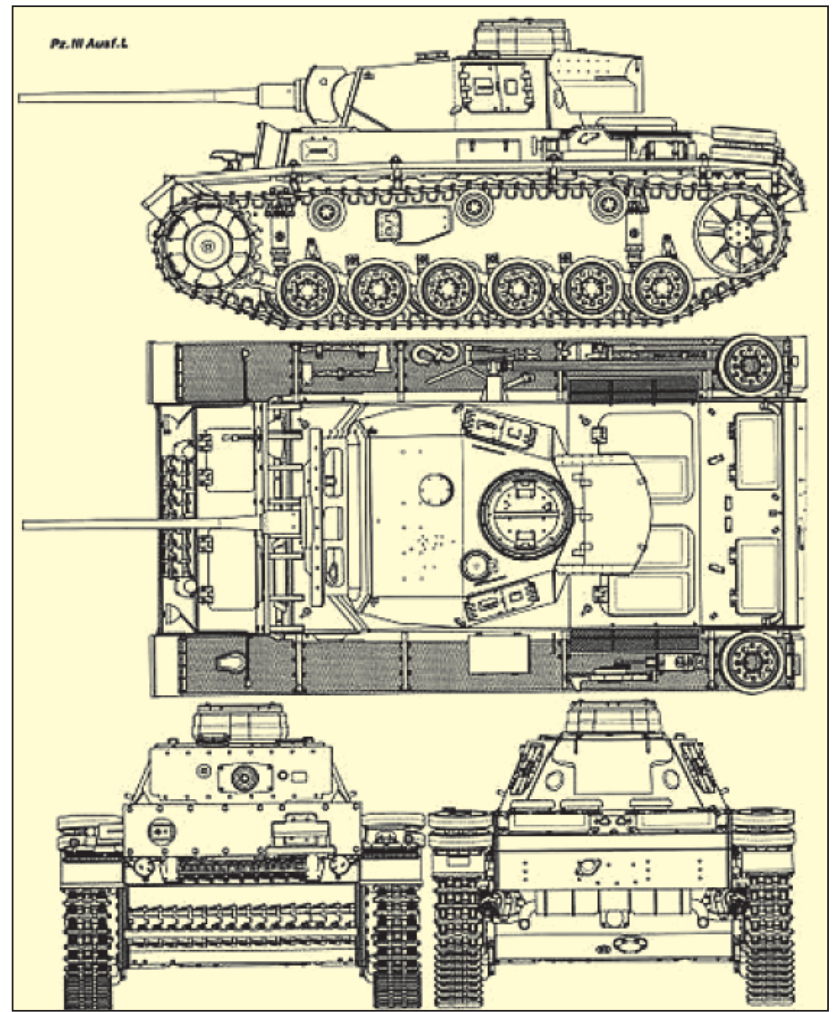

15. ábra. Az $5 \mathrm{~cm}$-es $\mathrm{L} / 60$-as löveggel szerelt $L$ változat négynézeti rajza

5 cm-es, L/60-as lövegű Pz III Ausf. M közepes harckocsit adott át a magyar 1. tábori páncélos hadosztálynak. Ezek nem kerültek a honvédség tulajdonába, csak a fronton történő alkalmazás idejére kölcsönözték azokat.

Amíg a kapott Pz IV típusra jól képzett, vagy átképzett, az addigi harcokban már részt vett magyar harckocsizók

16. ábra. Egy modellgyártó cég grafikája a 7,5 cm-es L/24-es löveggel szerelt Pz III Ausf. $\mathbf{N}$ változatról

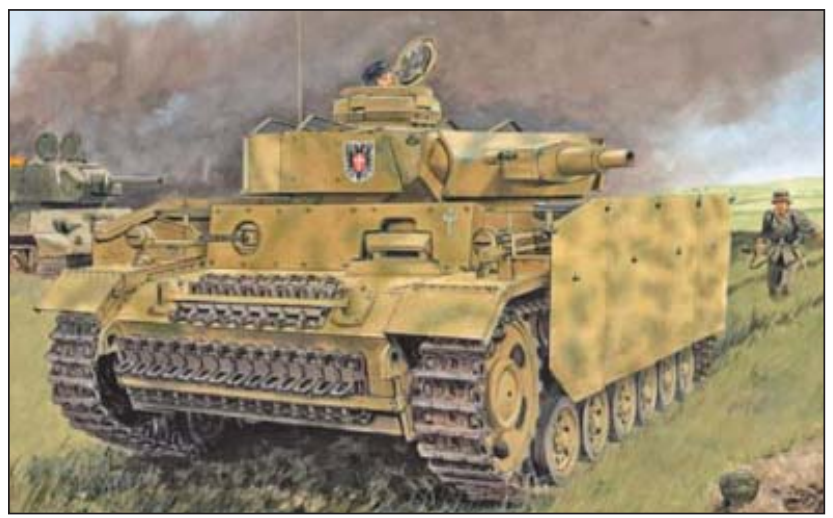


2. táblázat. A Pz III-as három változatának műszaki adatai

\begin{tabular}{|c|c|c|c|}
\hline Panzer III & Ausf. E & Ausf. L & Ausf. N \\
\hline Harci tömeg & $19500 \mathrm{~kg}$ & $21300 \mathrm{~kg}$ & $21300 / 23300 \mathrm{~kg}$ \\
\hline Kezelők száma & 5 & 5 & 5 \\
\hline Méretek H. ×Sz. × M. (mm) & $5690 \times 2810 \times 2335$ & $5380 \times 2910 \times 2435$ & $5650 \times 2970 * \times 2500$ \\
\hline Fajlagos talajnyomás & $0,63 \mathrm{~kg} / \mathrm{cm}^{3}$ & $0,99 \mathrm{~kg} / \mathrm{cm}^{3}$ & $1,03 \mathrm{~kg} / \mathrm{cm}^{3}$ \\
\hline Motor & Maybach HL 120 TRM, V12 & Maybach HL 120 TRM, V12 & Maybach HL 120 TRM, V12 \\
\hline Hengerürtartalom/LE & $11867 \mathrm{~cm}^{3} / 300$ LE & $11867 \mathrm{~cm}^{3} / 300$ LE & $11867 \mathrm{~cm}^{3} / 300 \mathrm{LE}$ \\
\hline Sebességek száma & $5+1$ & $6+1$ & $6+1$ \\
\hline Legnagyobb sebesség & $32 \mathrm{~km} / \mathrm{h}$ & $40 \mathrm{~km} / \mathrm{h}$ & $40 \mathrm{~km} / \mathrm{h}$ \\
\hline Lejtőmászó képesség & $30^{\circ}$ & $30^{\circ}$ & $30^{\circ}$ \\
\hline Lépcsőmászó képesség & $600 \mathrm{~mm}$ & $600 \mathrm{~mm}$ & $600 \mathrm{~mm}$ \\
\hline Gázlómélység & $800 \mathrm{~mm}$ & $800 \mathrm{~mm}$ & $800 / 1300 \mathrm{~mm}$ \\
\hline Árok-áthidaló képesség & $2600 \mathrm{~mm}$ & $2200 \mathrm{~mm}$ & $2000 \mathrm{~mm}$ \\
\hline Üzemanyagtartály (I) & 300 & 320 & 320 \\
\hline Fegyverzet (fő) & 3,7 cm KwK L/45 & 5 cm KwK L/60 & 7,5 cm KwK L/24 \\
\hline Fegyverzet (kiegészítō) & $3 \mathrm{db}$ MG34 7,92 mm & $2 \mathrm{db}$ MG34 7,92 mm & $2 \mathrm{db}$ MG34 7,92 mm \\
\hline Páncélvastagság & 14,5 cm körkörösen & $50-30 \mathrm{~mm}$ & $70-30 \mathrm{~mm}$ \\
\hline
\end{tabular}

* „Ostkette”-vel $3266 \mathrm{~mm}$

kerültek, a Pz III-asra beosztott személyzet azonban jobbára 1942 őszén a frontra kiküldött, megfelelő előképzettség nélküli póttartalékosokból állt, akik nem tudtak megfelelni a velük szemben támasztott követelményeknek.

Így a magyar Pz III-as harckocsik a magyar 30. harckocsiezred állományában, de német személyzettel harcoltak a szovjet áttörés és a 2. magyar hadsereg visszavonulása idején.

A Haditechnikai Intézet 1943-ban megvizsgált egy Pz III Ausf. M típusú harckocsit, amelynek a rendszeresítését az akkorra már túlhaladott műszaki jellemzői miatt nem javasolták.

1944 nyarán, a fronton harcoló magyar alakulatok ismét egy századnyi Pz III-as harckocsit vettek át a németektől, ugyancsak az $5 \mathrm{~cm}$-es L/60-as löveggel. Ezek a páncélosok az 1944. évi nyári harcok során felőrlődtek. A folyamatos visszavonulás során a sérült, esetleg még üzemképessé tehető páncélosok mentése a frontvonalból többnyire lehetetlen volt.

A hátra maradt, csak könnyen sérült $\mathrm{Pz}$ III-as páncélosokat azután a Vörös Hadsereg is alkalmazta, részben oktatásra. Emellett a zsákmányolt Pz. III-as harckocsik felhasználásával sorozatban gyártottak egy erre a páncélteknőre tervezett, szovjet 7,6 cm-es rohamlöveg-felépítményt is (SU 762).

\section{7. ábra. A szovjet felépítményű SU 762-es rohamlöveg}

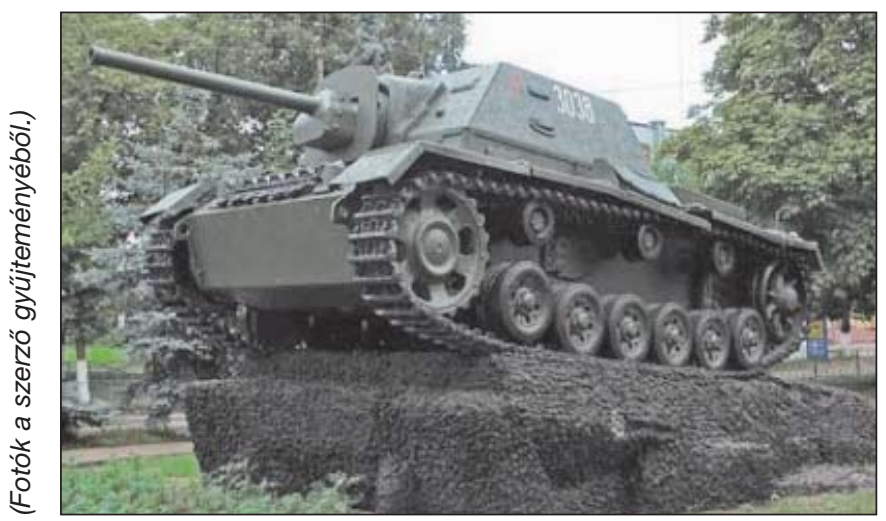

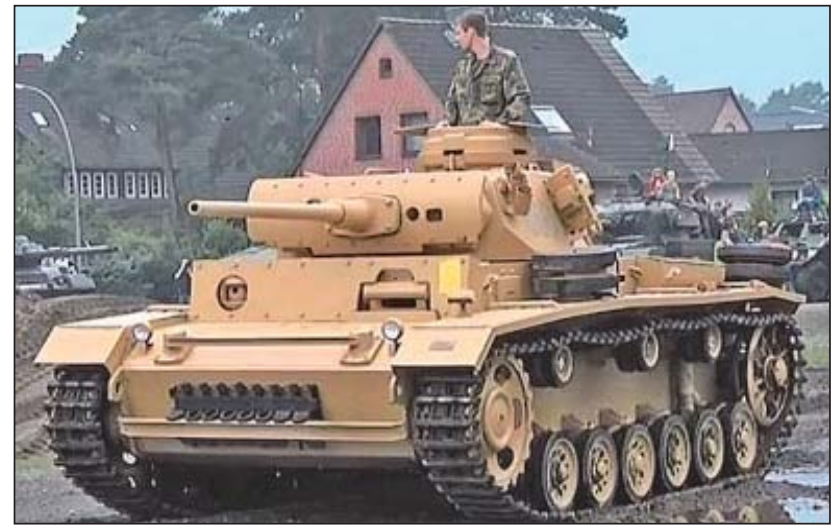

18. Egy üzemképes, túlélő példány a németországi Munster-Lager páncélos múzeumában

Ennek egyik példánya ma is látható az ukrajnai Sarniban. A páncélos alatt 1944 januárjában szakadt be a jég. Egy közeli folyóból emelték ki 1972-ben - személyzetével együtt.

\section{FoRRÁsOK}

Panzer III - Sztalnoj szimbol blitzkriga, Moszva 2008;

Mogyeliszt konsztruktor, Moszkva 1994;

Spielberger: Panzer-Kampfwagen III, Motorbuch Verlag 1974; Senger und Etterlin: Die deutschen Panzer 1926 - 1945, Lehmanns Verlag 1965;

Photo gallery \& profiles - Panzerkampfwagen III,

Periscopio publications, Greece 2006;

Bonhardt - Sárhidai - Winkler: A Magyar Királyi Honvédség fegyverzete, Zrínyi Kiadó, Bp.;

https://iremember.ru/memoirs/tankisti/polyanovskiy-uriymaksovich;

http://www.dragon-models.comhttp://www.dragonmodels.com;

Szüllő Attila és a szerző archívuma. 